\title{
Pelapisan (Coating) pada Benih Cabai Merah Besar (Capsicum annuum L) untuk Mencegah Penyakit Terbawa Benih
}

\author{
Anna Tefa ${ }^{\mathrm{a}}$, Aloysius Rusae ${ }^{\mathrm{b}}$, Febrianus Matnai $^{\mathrm{c}}$ \\ ${ }^{a}$ Fakultas Pertanian, Universitas Timor, Kefamenanu, TTU - NTT, Indonesia, email: annatefa@ rocketmail.com \\ ${ }^{b}$ Fakultas Pertanian, Universitas Timor, Kefamenanu, TTU - NTT, Indonesia, email: alorusae@yahoo.com \\ ${ }^{c}$ Fakultas Pertanian, Universitas Timor, Kefamenanu, TTU - NTT, Indonesia, email: ferrimatnai@gmail.com
}

\section{Article Info}

\section{Article history:}

Received 07 Juli 2019

Received in revised form 28 Agustus 2019

Accepted 22 September 2019

DOI:

https://doi.org/10.32938/sc.v4i01.814

Keywords:

Pelapisan (Coating)

PGPR

Fungisida antrakol

\begin{abstract}
Abstrak
Pengembangan Cabai Merah bertujuan meningkatkan produktivitas tanaman Cabai guna memenuhi permintaan konsumen. Penelitian in bertujuan mengetahui respon perkecambahan dan kejadian penyakit benih cabai merah besar pada perlakuan seed coating PGPR dan Fungisida antrakol. Penelitian ini telah dilakukan pada bulan Februari sampai bulan Mei 2019, di Laboratorium Fakultas Pertanian, Universitas Timor, Kelurahan Sasi, Kecamatan Kota Kefamenanu, Kabupaten Timor Tengah Utara, dengan menggunakan Rancangan Acak Lengkap (RAL) pola faktorial. Faktor Pertama: coating yaitu (C0) Tanpa Coating, (C1) Coating PGPR, (C2) Coating Fungisida Antrakol. Faktor kedua yakni: Periode simpan yaitu (P0) Tanpa Penyimpanan, (P1) Penyimpanan Bulan Pertama, (P2) Penyimpanan Bulan Kedua, (P3) Penyimpanan Bulan Ketiga. Hasil penelitian menunjukkan bahwa tidak terjadi interaksi antara faktor coating dan periode simpan terhadap parameter potensi tumbuh maksimum, kecepatan tumbuh sedangkan daya berkecambah, indeks vigor, keserempakan tumbuh, berat kering kecambah normal, kejadian penyakit menunjukkan terjadi interaksi. Perlakuan penyimpanan 2 bulan dan perlakuan coating PGPR memberikan prosentase pertumbuhan terbaik dan meminimalisir serangan penyakit.
\end{abstract}

\section{Pendahuluan}

Cabai merah besar (Capsicum annuum L.) merupakan salah satu jenis sayuran penting yang dibudidayakan secara komersial yang memiliki potens ekonomis dan telah di didomestikasi (Sulandari, 2004). Cabai Merah termasuk dalam tanaman hortikultura kelompok sayuran buah yang memiliki nilai ekonomis yang cukup tinggi. Produksi Cabai besar segar dengan tangkai tahun 2014 di Riau sebesar 9.355 ton dengan luas panen cabai besar sebesar 1.878 ha dan rata-rata produktivitas 498 ton ha-1. Dibandingkan dengan tahun 2013 terjadi kenaikan produksi sebesar 266 ton $(2.93 \%)$. Kenaikan ini disebabkan kenaikan luas panen sebesar 30 ha $(1.62 \%)$ dan kenaikan produktivitas sebesar 0.06 ton hektar-1 (1.28\%) (BPS, 2015). Pengembangan cabai merah bertujuan meningkatkan produktivitas tanaman Cabai guna memenuhi permintaan konsumen yang terus meningkat setiap tahun sejalan dengan meningkatnya jumlah penduduk dan berkembangnya industri yang membutuhkan bahan baku Cabai. Budidaya komoditi ini sering tidak luput dari serangan penyakit. Dua penyakit utama pada pertanaman Cabai adalah antraknosa dan bercak daun Cercospora. Kerugian yang disebabkan oleh antraknosa ini dapat mencapai $60 \%$ atau lebih (Duriatet al., 1991). Pada kondisi lingkungan yang optimum bagi perkembangan patogen, penyakit ini dapat menghancurkan seluruh areal pertanaman Cabai (Prajnanta, 1999). Penyakit antraknosa sukar dikendalikan karena infeksi patogennya bersifat laten dan sistemik. Cendawan $C$. capsici dapat menyerang inang pada segala fase pertumbuhan. Serangan patogen antraknosa pada fase pembungaan menyebabkan persentase benih terinfeksi tinggi walaupun benih tampak sehat (Sinaga, 1992). Untuk mencegah penyakit antraknosa perlu dilakukan penyebaran inokulum, yang mana penyebaran inokulum dilakukan melalui benih (seed borne)

Seed coating merupakan salah satu metode enhancement, yakni metode untuk memperbaiki mutu benih menjadi lebih baik dengan penambahan bahan kimia pada coating yang dapat mengendalikan dan meningkatkan perkecambahan (Copeland dan Mc Donald, 1995). Salah satu bahan yang digunakan adalah Plant Growth Promoting Rhizobacteria (PGPR). PGPR dapat memacu pertumbuhan tanaman dan menjadi agen pengendali hayati beberapa jenis patogen. Beberapa contoh bakteri PGPR adalah Bacillus subtilis, Serratia marcescens, dan Pseudomonas kelompok fluorescens. Berdasarkan penelitian yang dilakukan Sutariati dkk.,(2006), bakteri B. subtilis, S. marcescens, dan Pseudomonas kelompok fluorescens terbukti mampu memproduksi hormon auksin IAA yang berperan dalam pertumbuhan tanaman dan mampu meningkatkan viabilitas benih cabai. Tujuan penelitian ini adalah mengetahui respon perkecambahan dan kejadian penyakit benih cabai merah besar pada perlakuan seed coating PGPR dan fungisida antrakol.

\section{Metode}

Penelitian ini dilaksanakan pada bulan Februari-Mei 2019 di Laboratorium Fakultas Pertanian, Universitas Timor Kelurahan Sasi, Kecamatan Kota Kefamenanu, Kabupaten TTU. Alat dan bahan yang digunakan yakni Cabai merah besar, PGPR, Fungisida Antrakol, Air, Kertas stensil, Label dan Plastik es, Oven, Cawan Petridis, Germinator, Desikator, Timbangan analitik dan Handsprayer.Penelitian ini menggunakan Rancangan Acak Lengkap (RAL) pola faktorial. Faktor pertama adalah perlakuan coating yang terdiri atas 3 aras yaitu: Tanpa Coating (CO), Coating dengan PGPR (C1), Coating dengan fungsisida antracol (C2). Faktor 2 adalah periode simpan yang terdiri atas 4 aras yaitu : Tanpa Penyimpanan (P0), Penyimpana 1 Bulan (P1), Penyimpanan 2 Bulan (P2), Penyimpanan 3 Bulan (P3). Kombinasi perlakuan adalah C0P0, C1P0, C2P0, C0P1, C1P1, C2P1, C0P2, C1P2, C2P2, $\mathrm{C} 0 \mathrm{P} 3, \mathrm{C} 1 \mathrm{P} 3, \mathrm{C} 2 \mathrm{P} 3$. Perlakuan ini diulang sebanyak 3 kali sehingga seluruhnya terdapat 36 unit percobaan. Data hasil pengamatan dianalisis dengan menggunakan sidik ragam (anova). Rata-rata perlakuan dapat diuji lanjut dengan menggunakan Duncan Multiple Range Test (DMRT) dengan tingkat signifikasi $5 \%$ sesuai petunjuk Gomez dan Gomez, (1995). Analisis data menggunakan program SAS 9.1 .

\subsection{Potensi Tumbuh Maksimum (PTM) (\%)}

Potensi tumbuh maksimum (PTM) mengindikasikan viabilitas total. Penghitungan PTM didasarkan pada benih yang tumbuh (berkecambah) sampai hari ke-14 setelah tanam. Rumus untuk menghitung PTM yakni:

$$
\mathrm{PTM}=\frac{\sum K N+\sum \mathrm{Kab}}{\Sigma \text { benih yang di tanam }} \times 100 \%
$$

Dimana $: \Sigma K N=$ Jumlah kecambah normal sampai akhir pengamatan, $\Sigma$ $K a b=$ Jumlah kecambah abnormal sampai akhir pengamatan

\subsection{Daya Berkecambah (DB) (\%)}

Daya berkecambah dihitung berdasarkan jumlah kecambah normal (KN) pada hari pengamatan pertama dan pengamatan kedua. Pengamatan pertama dilakukan pada hari ke-7 sedangkan pengamatan kedua dilakukan pada hari ke14 setelah benih dikecambahkan. Daya berkecambah dihitung dengan menggunakan rumus sebagai berikut :

$$
\begin{aligned}
& \mathrm{DB}=\frac{\sum K N \text { hitungan } 1+\sum \mathrm{KN} \text { hitungan } \mathrm{II}}{\sum \text { benih yang dikecambah }} \times 100 \\
& \text { Dimana }: \sum K N=\text { jumlah kecambah normal }
\end{aligned}
$$

\subsection{Indeks Vigor (IV) (\%)}

Perhitungan didasari pada persentase kecambah normal $(\mathrm{KN})$ di hitungan pertama dan ke dua pada uji daya berkecambah yaitu hari ke-7 dan hari ke-14 HST untuk benih Cabai. Indeks Vigor dihitung dengan rumus:

$$
\begin{aligned}
& \mathrm{IV}=\frac{\sum K N \text { hitungan } I}{\sum \text { benih yang ditanamam }} \times 100 \% \\
& \text { Dimana: } \Sigma K N=\text { persentase kecambah normal }
\end{aligned}
$$

\subsection{Kecepatan Tumbuh (KCT) (\%/etmal)}

Pengamatan dilakukan terhadap jumlah kecambah normal sejak hari pertama hingga hari ke-14 setelah tanam. Perhitungan dilakukan dengan cara menjumlahkan hasil pembagian antara persentase kecambah normal yang tumbuh pada tiap pengamatan dengan waktu pengamatannya. Kecepatan tumbuh dihitung menggunakan rumus:

$$
\begin{aligned}
& \mathrm{KCT}=\frac{\% \mathrm{KN} \mathrm{ke-2}}{\text { et mal }}+\cdots+\frac{\% \mathrm{KN} \mathrm{ke}-\mathrm{n}}{\text { et mal }} \\
& \text { Dimana: } 1 \text { et mal }=24 \mathrm{jam}, \% \mathrm{KN}=\text { persentase kecambah normal }
\end{aligned}
$$

\subsection{Keserempakan Tumbuh (\%)}

Pengamatan dilakukan terhadap kemampuan benih untuk membentuk kecambah normal (\%) pada hitungan pertama (hari ke-12). Keserempakan tumbuh dihitung menggunakan rumus:

$$
\begin{aligned}
& \mathrm{KT}=\frac{\sum K N \mathrm{ke}-5}{\sum \text { benih yang ditanaman }} \times 100 \% \\
& \text { Dimana : } \Sigma K N=\text { jumlah kecambah normal }
\end{aligned}
$$

\subsection{Berat Kering Kecambah Normal (BKKN)}

Berat kering kecambah normal diamati pada hari pengamatan kedua (hari ke-14) dengan cara memisahkan kecambah normal dari cadangan makanannya. Kecambah tersebut kemudian dimasukkan kedalam amplop dan dioven pada suhu $60^{\circ} \mathrm{C}$ selama $3 \times 24$ jam. Setelah dioven amplop yang berisi kecambah tersebut dimasukkan kedalam desikator selama \pm 45 menit kemudian ditimbang.

\subsection{Kejadian Penyakit (\%)}

Pengamatan kejadian penyakit yakni menghitung jumlah tanaman sampel yang terserang patogen. Menurut Zadoks dan Schein (1979) menghitung persentase kejadian penyakit (KP) digunakan rumus sebagai berikut: 
$\mathrm{KP}=\frac{\mathrm{n}}{\mathrm{k}} \times 100 \%$

Dimana: $K P=$ Kejadian Penyakit, $n=$ Jumlah tanaman yang terserang patogen, $k=$ Jumlah tanaman yang diamati dalam setiap perlakuan

\section{Hasil dan Pembahasan}

\subsection{Potensi Tumbuh Maksimum (PTM) (\%)}

Hasil sidik ragam (anova) menunjukkan tidak terjadi interaksi antara perlakuan coating dan penyimpanan terhadap parameter potensi tumbuh maksimum. Perlakuan penyimpanan bulan ke-2 menunjukkan persentase tertinggi $94.00 \%$ dan tidak menunjukkan beda nyata dengan perlakuan lainnya. Perlakuan coating mengunakan PGPR memperoleh persentase tertinggi $94.00 \%$ dan tidak berbeda nyata dengan perlakuaan lainnya. Data dapat dilihat pada tabel 1 .

Tabel 1. Pengaruh Perlakuan Coating dan Penyimpanan terhadap Potensi Tumbuh Maksimum pada Tanaman Cabai

\begin{tabular}{ccccc}
\hline \multirow{2}{*}{ Penyimpanan } & \multicolumn{3}{c}{ Coating } & \multirow{2}{*}{ Rerata } \\
\cline { 2 - 4 } & Kontrol & PGPR & Fungisida Antrakol & \\
\hline Tanpa (Kontrol) & 85.33 & 94.67 & 93.33 & $91.11^{\mathrm{a}}$ \\
Penyimpanan 1 & 94.67 & 93.33 & 93.33 & $93.33^{\mathrm{a}}$ \\
Penyimpanan 2 & 93.33 & 94.67 & 94.00 & $94.00^{\mathrm{a}}$ \\
Penyimpanan 3 & 90.67 & 93.33 & 90.67 & $91.56^{\mathrm{a}}$ \\
\hline Rerata & $91.00^{\mathrm{a}}$ & $94.00^{\mathrm{a}}$ & $92.83^{\mathrm{a}}$ & $(-)$ \\
\hline
\end{tabular}

Keterangan : Angka pada barisan dan kolom diikuti huruf yang sama menunjukkan beda pada tingkat nyata (a) $5 \%$ menurut uji DMRT (-) tidak terjadi interaksi antar faktor

\subsection{Daya Berkecambah (DB) $(\%)$}

Hasil sidik ragam (anova) menunjukkan terjadi interaksi antara perlakuan penyimpanan dan coating pada parameter daya berkecambah. Daya berkecambah tertinggi terdapat pada perlakuan coating PGPR dengan lama penyimpaann 2 bulan $96.00 \%$ dan berbeda nyata dengan perlakuan kontrol dengan penyimpanan 1 bulan. Data dapat dilihat pada tabel 2.

Tabel 2. Pengaruh Perlakuan Coating dan Penyimpanan terhadap Daya Berkecambah pada Tanaman Cabai

\begin{tabular}{ccccc}
\hline \multirow{2}{*}{ Penyimpanan } & \multicolumn{3}{c}{ Coating } & \multirow{2}{*}{ Rerata } \\
\cline { 2 - 4 } & Kontrol & PGPR & Fungisida Antrakol & \\
\hline Tanpa (Kontrol) & $85.33 \mathrm{ab}$ & $93.00 \mathrm{a}$ & $96.00 \mathrm{a}$ & 92.44 \\
Penyimpanan 1 & $81.33 \mathrm{~b}$ & $93.33 \mathrm{a}$ & $96.00 \mathrm{a}$ & 90.22 \\
Penyimpanan 2 & $88.00 \mathrm{ab}$ & $96.00 \mathrm{a}$ & $94.67 \mathrm{a}$ & 92.44 \\
Penyimpanan 3 & $90.67 \mathrm{ab}$ & $93.33 \mathrm{a}$ & $90.67 \mathrm{ab}$ & 91.56 \\
\hline Rerata & 86.33 & 94.33 & 94.33 & $(+)$ \\
\hline
\end{tabular}

Keterangan : Angka pada barisan dan kolom diikuti huruf yang sama menunjukkan beda pada tingkat nyata $(\alpha)$ 5\% menurut uji DMRT $(+)$ tidak terjadi terjadi interaksi antar faktor

\subsection{Indeks Vigor (IV) (\%)}

Hasil sidik ragam (anova) menunjukkan bahwa pada parameter indeks vigor terjadi interaksi. Perlakuan tanpa penyimpanan dan tanpa coating menunjukkan indeks vigor tertinggi yaitu $69.33 \%$ berbeda nyata dengan perlakuan tanpa coating pada penyimpanan bulan ke-1 dan perlakuan coating fungisida pada penyimpanan bulan ke-2. Data dapat dilihat pada tabel 3

Tabel 3. Pengaruh Perlakuan Coating dan Penyimpanan terhadap Indeks Vigor Pada Tanaman Cabai

\begin{tabular}{ccccc}
\hline \multirow{2}{*}{ Penyimpanan } & \multicolumn{3}{c}{ Coating } & \multirow{2}{*}{ Rerata } \\
\cline { 2 - 4 } & $($ Kontrol) & PGPR & Fungisida Antrakol & \\
\hline Tanpa (Kontrol) & $69.33^{\mathrm{a}}$ & $68.00^{\mathrm{ab}}$ & $62.67^{\mathrm{abc}}$ & 66.67 \\
Penyimpanan 1 & $49.33^{\mathrm{c}}$ & $62.67^{\mathrm{abc}}$ & $62.67^{\mathrm{abc}}$ & 58.33 \\
Penyimpanan 2 & $45.33^{\mathrm{abc}}$ & $58.67^{\mathrm{abc}}$ & $48.00^{\mathrm{c}}$ & 50.67 \\
Penyimpanan 3 & $53.00^{\mathrm{abc}}$ & $68.00^{\mathrm{ab}}$ & $57.33^{\mathrm{abc}}$ & 59.44 \\
\hline Rerata & 54.33 & 64.33 & 57.67 & $(+)$
\end{tabular}

Keterangan : Angka pada barisan dan kolom diikuti huruf yang sama menunjukkan beda padatingkat nyata $(\alpha) 5 \%$ menurut uji DMRT (+) terjadi interaksi antar faktor

\subsection{Kecepatan Tumbuh (KCT) (\%/etmal)}

Hasil sidik ragam (anova) menunjukkan bahwa tidak terjadi interaksi antara perlakuan penyimpanan dan coating pada parameter kecepatan tumbuh.

Tabel 4. Pengaruh Perlakuan coating dan Penyimpanan terhadap Kecepatan Tumbuh pada Tanaman Cabai

\begin{tabular}{ccccc}
\hline \multirow{2}{*}{ Penyimpanan } & \multicolumn{3}{c}{ Coating } & \multirow{2}{*}{ Rerata } \\
\cline { 2 - 4 } & Kontrol & PGPR & Fungisida Antrakol & \\
\hline Tanpa (Kontrol) & 15.07 & 15.75 & 14.53 & $15.12^{\mathrm{a}}$ \\
Penyimpanan 1 & 14.45 & 17.98 & 14.53 & $15.65^{\mathrm{a}}$ \\
Penyimpanan 2 & 17.62 & 15.57 & 14.10 & $15.76^{\mathrm{a}}$ \\
Penyimpanan 3 & 15.55 & 15.30 & 14.77 & $15.21^{\mathrm{a}}$ \\
\hline Rerata & $15.67^{\mathrm{a}}$ & $16.15^{\mathrm{a}}$ & $14.48^{\mathrm{a}}$ & $(-)$ \\
\hline Keterangan
\end{tabular}

Keterangan : Angka pada barisan dan kolom diikuti huruf yang sama menunjukkan beda pada tingkat nyata( $\alpha$ ) 5\% menurut uji DMRT (-) terjadi interaksi antar factor

Perlakuan coating PGPR memberikan persentase tertinggi $16,15 \%$ dan tidak berbeda nyata dengan perlakuan lainnya. Perlakuan penyimpanan 2 bulan memberikan persentase tertinggi $15,76 \%$ dan tidak berbeda nyata dengan perlakuan lainnya. Data dapatdilihat pada tabel 4

\subsection{Keserempakan Tumbuh(KST)}

Hasil sidik ragam (anova) menunjukkan bahwa terjadi interaksi antara perlakuan penyimpanan dan coating terhadap pengamatan keserempakan tumbuh. Perlakuan benih pada penyimpanan bulan ke 1 dan bulan ke 2 yang dicoating dengan PGPR menunjukkan prosentase tertinggi yaitu $100 \%$ berbeda nyata dengan perlakuan tanpa coating yang disimpan selama 3 bulan yaitu $88 \%$. Data dapat dilihat pada tabel 5 .

Tabel 5. Pengaruh Coating dan Penyimpanan terhadap Keserempakan Tumbuh pada Tanaman Cabai

\begin{tabular}{ccccc}
\hline \multirow{2}{*}{ Penyimpanan } & \multicolumn{3}{c}{ Coating } & \multirow{2}{*}{ Rerata } \\
\cline { 2 - 5 } & Kontrol & PGPR Fungisida Antrakol & \\
\hline Tanpa (Kontrol) & $89.33 \mathrm{ab}$ & $97.33 \mathrm{ab}$ & $98.67 \mathrm{a}$ & $95.11^{\mathrm{a}}$ \\
Penyimpanan 1 & $90.67 \mathrm{ab}$ & $100.00 \mathrm{a}$ & $96.00 \mathrm{ab}$ & $95.56^{\mathrm{a}}$ \\
Penyimpanan 2 & $98.67 \mathrm{a}$ & $100.00 \mathrm{a}$ & $90.67 \mathrm{ab}$ & $96.44^{\mathrm{a}}$ \\
Penyimpanan 3 & $88.00 \mathrm{~b}$ & $98.67 \mathrm{a}$ & $96.00 \mathrm{ab}$ & $94.22^{\mathrm{a}}$ \\
\hline Rerata & $91.67^{\mathrm{a}}$ & $99.00^{\mathrm{a}}$ & $95.33^{\mathrm{a}}$ & $(+)$ \\
\hline
\end{tabular}

Keterangan : Angka pada barisan dan kolom diikuti huruf yang sama menunjukkan beda pada tingkat nyata $(\alpha) 5 \%$ menurut uji DMRT (+) terjadi interaksi antar faktor

\subsection{Berat Kering Kecambah Normal (BKKN)}

Hasil sidik ragam (anova) menunjukkan bahwa terjadi interaksi antara perlakuan penyimpanan dan coating pada pengamatan berat kering kecambah normal. Perlakuan tanpa coating PGPR dengan tanpa penyimpanan coating PGPR dengan penyimpanan 1 bulan dan tanpa coating dengan penyimpanan 3 bulan memberikan persentase tertinggi $0,10 \%$ dan tidak berbeda nyata dengan perlakuan lainnya. Data dapat dilihat pada tabel 6.

Tabel 6. Pengaruh Perlakuan Coating dan Penyimpanan terhadap Berat Kering Kecambah Normal pada Tanaman Cabai

\begin{tabular}{ccccc}
\hline \multirow{2}{*}{ Penyimpanan } & \multicolumn{3}{c}{ Coating } & \multirow{2}{*}{ Rerata } \\
\cline { 2 - 4 } & Kontrol & PGPR & Fungisida Antrakol & \\
\hline Tanpa (Kontrol) & $0.09 \mathrm{a}$ & $0.10 \mathrm{a}$ & $0.06 \mathrm{a}$ & 0.08 \\
Penyimpanan 1 & $0.09 \mathrm{a}$ & $0.10 \mathrm{a}$ & $0.07 \mathrm{a}$ & 0.09 \\
Penyimpanan 2 & $0.08 \mathrm{a}$ & $0.05 \mathrm{a}$ & $0.08 \mathrm{a}$ & 0.07 \\
Penyimpanan 3 & $0.10 \mathrm{a}$ & $0.05 \mathrm{a}$ & $0.08 \mathrm{a}$ & 0.08 \\
\hline Rerata & 0.09 & 0.08 & 0.08 & $(-)$ \\
\hline Keterangan
\end{tabular}

Keterangan : Angka pada barisan dan kolom diikuti huruf yang sama menunjukkan beda pada tingkat nyata( $\alpha$ ) $5 \%$ menurut uji DMRT (-) tidak terjadi interaksi antar faktor.

\subsection{Kejadian Penyakit (KP) (\%)}

Hasil sidik ragam (anova) menunjukkan bahwa terjadi interaksi antara perlakuan penyimpanan dan coating pada parameter kejadian penyakit (KP) Benih yang disimpan selama 1 bulan tanpa perlakuan coating menunjukkan prosentase kejadian penyakit tertinggi yaitu $13.33 \%$ berbeda nyata dengan coating PGPR tanpa penyimpanan $0.00 \%$. Data dapat dilihat pada tabel 7 .

Tabel 7. Pengaruh Perlakuan Coating dan Penyimpanan terhadap Kejadian Penyakit pada Tanaman Cabai

\begin{tabular}{ccccc}
\hline \multirow{2}{*}{ Penyimpanan } & \multicolumn{3}{c}{ Coating } & \multirow{2}{*}{ Rerata } \\
\cline { 2 - 4 } & Kontrol & PGPR & Fungisida Antrakol & \\
\hline Tanpa (Kontrol) & $4.00 \mathrm{ab}$ & $0.00 \mathrm{~b}$ & $1.33 \mathrm{ab}$ & 1.78 \\
Penyimpanan 1 & $13.33 \mathrm{a}$ & $2.67 \mathrm{ab}$ & $1.33 \mathrm{ab}$ & 5.78 \\
Penyimpanan 2 & $4.00 \mathrm{ab}$ & $5.33 \mathrm{ab}$ & $9.33 \mathrm{ab}$ & 6.22 \\
Penyimpanan 3 & $8.00 \mathrm{ab}$ & $8.00 \mathrm{ab}$ & $6.67 \mathrm{ab}$ & 7.56 \\
\hline Rerata & 7.33 & 4.00 & 4.00 & $(+)$ \\
\hline Keterangan : Angka pada barisan dan kolom diikuti huruf yang sama menunjukkan beda
\end{tabular}

pada tingkat nyata $(\alpha) 5 \%$ menurut uji DMRT $(+)$ terjadi interaksi antar faktor

Hasil penelitian menunjukkan tidak terjadi interaksi antara kombinasi perlakuan dan coating pada parameter pengamatan potensi tumbuh maksimum, kecepatan tumbuh. Parameter pengamatan yang terjadi interaksi antara lain parameter pengamatan berat kering kecambah normal, keserempakan tumbuh, indeks vigor, kejadian penyakit, daya berkecambah dan terjadi beda nyata selama penyimpanan. Rata-rata perlakuan menunjukkan tidak terjadi pengaruh nyata antara perlakuan namun pada perlakuan coating PGPR cenderung mununjukkan persentase kejadian penyakit terendah $0,00 \%$ dibandingkan dengan tanpa perlakuan coating. Hal ini menunjukkan bahwa perlakuan coating mampu menjaga dan meminimalisir penyakit terbawa benih. Kenyataan ini senada dengan penelitian Nasrun \& Nuryani (2007) bakteri di dalam rizosfer secara tidak langsung berpengaruh terhadap pertumbuhan tanaman yaitu sebagai agen pengendali hayati. Bakteri probiotik seperti Pseudomonas flourescens dan Bacillus sp, berperan sebagai pengendali penyakit antraknosa pada tanaman. Menurut Ilyas (2003) fungsi seed coating adalah meningkatkan daya simpan, mengurangi resiko tertular penyakit, pembawa zat aditif dan memperbaiki penampilan benih. Menurut (Kuswanto 2003), seed coating merupakan proses pembungkusan benih dengan zat tertentu, yang antara lain bertujuan untuk meningkatkan kinerja benih pada waktu benih dikecambahkan, melindungi benih dari gangguan atau pengaruh kondisi lingkungan selama dalam penyimpanan atau alam rantai pemasaran, mempertahankan kadar air 
benih, menyeragamkan ukuran benih, memudahkan penyimpanan benih dan mengurangi dampak kondisi tempat penyimpanan serta memperpanjang daya simpan benih.

Menurut Copeland dan Mc Donald (2001) coating umumnya menggunakan tambahan zat tertentu yang kompatibel dengan benih agar kualitas benih tetap terjaga dan mempercepat perkecambahan sehingga tidak terganggu seperti pestisida, hormon tumbuh, dan agen biologis (bakteri dan cendawan) lainnya. Coating merupakan perlakuan yang dapat digunakan untuk melindungi benih Cabai dari serangan penyakit yang menyebabkan pertumbuhan benih Cabai terhambat (Copeland \& Mc Donald 2001). Lamanya penyimpanan menunjukkan data tidak ada pengaruh nyata antara perlakuan namun pada perlakuan penyimpanan 2 bulan cenderung meningkatkan daya kecambah normal dan kecepatan tumbuh tercepat. Daya berkecambah benih merupakan salah satu parameter yang bersifat langsung menggambarkan viabilitas benih (Hendrawati, 1993). Daya berkecambah benih ini dapat digunakan sebagai parameter untuk menetapkan umur simpan suatu benih dan untuk uji tingkat kadar air yang terbaik untuk penyimpanan. Penentuan umur simpan benih umumnya dilakukan secara empiris dengan percobaan menyimpan benih pada berbagai kondisi dan lama penyimpanan. Kemudian umur simpannya ditentukan berdasarkan mutu benih pada perlakuan umur simpan tertentu saat benih memenuhi persyaratan mutu standar atau yang masih dapat diterima. Dalam uji umur simpan parameter penting ialah kadar air awal benih dan jenis kemasan (Maryanto, 1994), kelembaban dan suhu ruang penyimpanan (Hartini, 1997).

\section{Simpulan}

Berdasarkan hasil penelitian dapat disimpulkan bahwa perlakuan penyimpanan 2 bulan dan coating PGPR memberikan persentase pertumbuhan terbaik. Coating PGPR dapat menjaga dan meminimalisir kejadian penyakit pada benih Cabai besar.

\section{Pustaka}

Copeland LO, Mc Donald MB. 2001. Seed Science and Technology 4 th edition. Kluwer

Duriat, A.S., J. Vos, B. Martowo, M. Stallen, N. Nurtika, J. Buurma. 1991 Report of a workshop on hot pepper planning. Internal Communication No. 36 of lembang Horticultural Research Institute LEHRI and ATA395, 15pp

Gomez, K. A. and Gomez A. A. 1995. Prosedur Statistik Untuk Penelitian Pertanian. Edisi ke 2. UI Press: Jakarta

Hartini, R. 1997. Pengaruh kondisi simpan dan perlakuan invigorasi pasca penyimpanan ter-hadap viabilitas dan vigor benih Kedele (Glycine max (L) Merill) pada beberapa periode simpan. Skripsi Jurusan Budidaya Pertanian Fakultas Pertanian IPB

Hendrawati, M. 1993. Pengaruh Tingkat Kadar Air Benih Pada permulaan penyimpanan Terhadap Viabilitas, Vigor Pertumbuhan dan Hasi Tanaman Cabai (Capsicum annum L.) Fakultas Pertanian Universitas Andalas, Padang

Ilyas, S. 2003. Teknologi Pelapisan Benih. Makalah Seminar Benih Pellet Fakultas Pertanian. IPB. Bogor. 16 hal.

Kuswanto, H. 2003. Teknologi Pemrosesan, Pengemasan dan Penyimpanan Benih. Yogyakarta:Kanisius

Maryanto, A. 1994. Pengaruh kadar air awal, kondisi simpan dan wadah simpan terhadap lama simpan benih kedelai (Glycine max L.). Skripsi Jurusan Budidaya Pertanian Fakultas Pertanian IPB

Nasrun dan Y. Nuryani. 2007. Penyakit Layu Bakteri pada Nilam dan Strategi Pengendaliannya. Balai Penelitian Tanaman Obat dan Aromatik. Bogor

Prajnanta, F. 1999. Agribisnis Cabai Hibrida. Cetakan ke-6. Penebar Swadaya, Jakarta

Sinaga, M. S. 1992. Kemungkinan Pengendalian Hayati Bagi Colletotrichum capsici (Syd) Bult. Et Bisby Penyebab Antraknosa pada Cabai. Laporan Akhir: Penelitian Pendukung PHT dalam Rangka Pelaksanaan Program Nasional Pengendalian Hama Terpadu. Kerjasama Proyek Prasarana Fisik Bappenas dengan Fakultas Pertanian. IPB. Bogor. 29 hal

Sutariati GAK, Widodo, Sudarsono, Ilyas S. 2006. Pengaruh perlakuan rizobakteri pemacu pertumbuhan tanaman terhadap viabilitas benih serta pertumbuhan bibit tanaman cabai. Bul. Agron. (34)(1):46-54

Sulandari S. 2004. Karakterisasi Biologi, Serologi dan Analisis Sidik Jari DNA Virus Penyebab Penyakit Daun Keriting Kuning Cabai. Disertasi SPs IPB. Bogor

Zadoks, J.C dan R.D. Schein. 1979. Epidemology and Plant Disease Management. Oxford University Press: New York 